J. Lake Sci. (湖泊科学), 2012, 24(4):577-585

http: //www.jlakes.org. E-mail: jlakes@niglas.ac.cn

(C) 2012 by Journal of Lake Sciences

\title{
黑龙江省安兴湿地秋季浮游植物群落结构”
}

韩欢欢, 范亚文**

(哈尔滨师范大学生命科学与技术学院, 哈尔滨 150025 )

摘 要: 于 2010 年 10 月 (秋季) 对黑龙江省安兴湿地浮游植物群落组成、丰度及优势种进行分析. 共设置 9 个采样点, 经 鉴定共有浮游植物 146 个分类单位,包括 128 种 17 变种 1 变型, 隶属于 6 门 8 纲 12 目 25 科 45 属, 其中绿藻为优势门类, 占浮游植物总数的 $39.7 \%$, 裸藻次之, 占浮游植物总数的 $30.8 \%$, 硅藻居第三位, 占浮游植物总数的 $21.9 \%$, 调查期间浮 游植物的总丰度为 $181.4 \times 10^{6} \mathrm{cells} / \mathrm{L}$. 优势度分析显示, 安兴湿地秋季各采样点的浮游植物优势种都在 3 个以上, 主要 优势种有细粒囊裸藻 ( Trachelomonas granulosa Playf.) 、梅尼小环藻 (Cyclotella meneghiniana Kütz. ) 、细粒囊裸藻齿领变种 (Trachelomonas granulosa var. crenulatocollis (Szab.) Hub. -Pest.) 等. 样点聚类和非度量多维标度分析表明,9 个采样点浮游 植物群落在相似度 $60 \%$ 时可分为 5 组, 各样点浮游植物种类在空间组成上相似性低, 差异性较大, 主要与其生境特点相 关. 典范对应分析显示优势种类变化与环境条件相一致,主要受温度、 $\mathrm{pH}$ 的影响. 此外, 在安兴湿地内还鉴定出大量的 $\beta$ 中污带指示种,结合多样性指数分析,本文初步推断安兴湿地水质可能受到了一定的污染.

关键词: 安兴湿地;浮游植物; 群落结构

\section{Phytoplankton community structure in autumn of Anxing Wetland, Heilongjiang Province}

\author{
HAN Huanhuan \& FAN Yawen \\ (College of Life Science and Technology, Harbin Normal University, Harbin 150025, P. R. China)
}

\begin{abstract}
This paper is about the structure of phytoplankton communities in the autumn of 2010 in Anxing Wetland, Heilongjiang Province, China. The abundance of phytoplankton communities, cell density and dominant species were analyzed. In total, 146 taxa were identified from nine sampling sites. The 146 taxa included 6 divisions, 8 classes, 12 orders, 25 families, 45 genera, 128 species, 17 varieties and 1 form. Chlorophyta were dominant and accounted for $39.7 \%$ of the total phytoplankton, while Euglenophyta and Bacillariophyta accounted for $30.8 \%$ and $21.9 \%$, respectively. The abundance of phytoplankton was $181.4 \times 10^{6}$ cells/L. Dominance analysis showed that there were more than three dominant species at each sampling site, including Trachelomonas granulosa Playf., Cyclotella meneghiniana Kütz. and Trachelomonas granulosa var. crenulatocollis ( Szab. ) Hub. -Pest. . Cluster and non-metric Multi Dimensional Scaling analysis showed that nine sampling sites were divided into five groups and the composition of phytoplankton communities were significant different spatially when the similarity of the phytoplankton community reached to $60 \%$. That was related to different ecological characteristics of each site. Canonical Correspondence Analysis showed that dominant specie change was mainly influenced by temperature and $\mathrm{pH}$. In addition, a large number of $\beta$-mesosaprobic zone indicators and lower diversity index were monitored in Anxing Wetland, suggesting that the water quality from the wetlands might have been polluted.
\end{abstract}

Keywords: Anxing Wetland; phytoplankton; community structure

浮游植物是湿地生态系统的重要组成部分、食物链的基础环节, 其组成与多样性的变化将直接影响生 态系统的结构与功能 ${ }^{[1]}$, 在湿地生态系统的研究中具有重要意义. 浮游植物群落的种类组成、数量分布和多 样性等群落结构特征是评价水环境质量的重要标准, 可以反映水环境污染状况 ${ }^{[2]}$. 因此, 浮游植物已成为生

* 国家自然科学基金项目 (30870157,31070183,31110103015) 和黑龙江省科技厅项目 (C200828) 联合资助. 2011 09-02 收稿;2011-10-25 收修改稿. 韩欢欢,女,1986 年生,硕士研究生;E-mail : swxhhh@ 126. com.

** 通信作者;E-mail:fanyaw@ yahoo.com.cn. 
物监测以及评价水质和水体营养状况的重要生物指标, 在国内外已被广泛采用. Diaz 等 ${ }^{[3]}$ 、Lepistö 等 ${ }^{[4]}$ 都曾 指出浮游植物是反映水生态环境的良好指示生物. 近年来我国许多学者利用浮游植物来监测和评价水体的 污染状况, 如李秋华等 ${ }^{[5]}$ 对南亚热带调水水库春季浮游植物群落的结构与动态进行调查和分析, 结果表明 水温是引起水库浮游植物种类组成变化的主要原因; 覃雪波等 ${ }^{[6]}$ 运用相关分析和灰关联分析对安邦河湿地 浮游植物数量与环境因子关系进行研究, 结果表明安邦河湿地浮游植物与环境因子密切相关, 灰关联分析 揭示了影响安邦河湿地浮游植物最大因子是水体营养盐中可溶性无机磷; 孟顺龙等 ${ }^{[7-8]}$ 利用浮游植物生态 学特征并结合多样性指数对太湖五里湖的浮游植物群落结构进行分析, 表明 2007-2008 年五里湖浮游植物 群落结构比较复杂、群落信息含量较大,群落结构处于较完整的状态.

安兴湿地 $\left(46^{\circ} 07^{\prime} \sim 46^{\circ} 40^{\prime} \mathrm{N}, 129^{\circ} 26^{\prime} \sim 130^{\circ} 13^{\prime} \mathrm{E}\right)$ 自然保护区位于黑龙江省哈尔滨市依兰县, 倭肯河左 岸中下游一级支流上, 是三江平原湿地的一部分, 属于省级内陆湿地, 湿地总面积 $11000 \mathrm{hm}^{2}$, 其中水库面积 $96 \mathrm{hm}^{2}$. 安兴湿地是一个天然蓄水库, 具有调节区域气候和补充空气湿度、改善环境的功能,并且拥有宝贵的 淡水、生物、土地等资源,也是重要的物种基因库. 近几年,安兴湿地周边农田不断开旺扩大,这可能会加剧 水环境中化学用药的污染. 2002 年安兴湿地被批准为黑龙江省自然保护区, 是依兰县重点保护湿地之一. 目 前对安兴湿地的资源调查大多集中在高等动植物, 其中有记录的高等植物 72 科 362 种, 野生动物 254 种, 其 中鸟类 157 种、爬行类 6 种、鱼类 55 种 ${ }^{[9]}$, 而对安兴湿地内浮游植物的相关研究在国内外未见报道. 本文通 过对安兴湿地浮游植物的监测和调查, 可为国内湿地浮游植物研究提供资料, 为湿地状况的动态监测提供 基本数据.

\section{1 材料与方法}

\section{1 采样点设置}

根据安兴湿地生态特点,2010 年秋季在安兴湿地内共设置 9 个采样点 (图 1), 每个样点采集 2 个标本, 样点均匀设置并具有代表性, 分别位于湿地核心区（I 点、II 点）、灌溉区（III点、IV 点）、农田区（V点）、靠近 村庄 (VI点)、人水口 (VII点)、靠近道路 (VIII点)、出水口 ( IX 点). V 点靠近农田, 受农业生产过程中施用肥料 的影响较大; VI点靠近村庄, 但村庄无污水排人; VIII点靠近道路, 在一定程度上会受人为活动的影响; $\mathrm{V}$ 点和 IX点周围有少量水草分布, 但各样点均无高等植物覆盖.

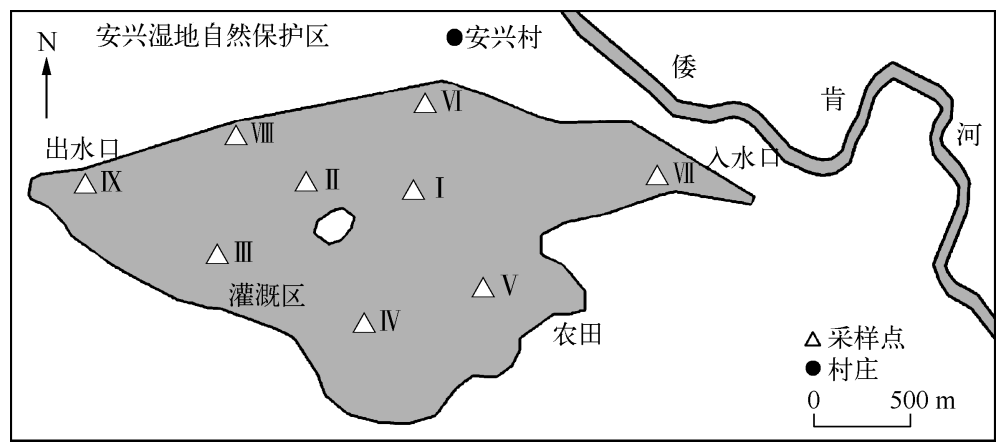

图 1 安兴湿地采样点分布

Fig. 1 Distribution of sampling sites in Anxing Wetland

\section{2 样品的采集、计数与指标测定}

定性样品中浮游植物采集使用 $25^{\#}$ 浮游网,在水面下 $0.5 \mathrm{~m}$ 处作“ $\infty$ ”字形捞取,采集的样品用 $4 \%$ 甲醛 固定保存. 定量样品的采集是利用采水器在水下 $1 \mathrm{~m}$ 处取 $1 \mathrm{~L}$ 水样, 用 $15 \mathrm{ml}$ 鲁哥氏剂固定后沉淀 $48 \mathrm{~h}$ 并浓 缩至 $30 \mathrm{ml}^{[10-11]}$. 取 $0.1 \mathrm{ml}$ 浓缩水样于浮游生物计数框中, 在 $10 \times 40$ 倍光学显微镜下进行鉴定并计数, 种类 鉴定依据《中国淡水藻类——系统、分类及生态》等 ${ }^{[12-20]}$.

采集现场测量指标有水温 (WT)、 $\mathrm{pH}$ 、电导率( SpCond.). 将自水面 $0.5 \mathrm{~m}$ 深处采集的水样 $24 \mathrm{~h}$ 内带回 
实验室, 进行溶解氧 $(D O)$ 、生化需氧量 $\left(\mathrm{BOD}_{5}\right)$ 、化学需氧量 $(\mathrm{COD})$ 、总磷 $(\mathrm{TP})$ 、总氮 $(\mathrm{TN})$ 和浊度 $($ Turb. $)$ 等理化指标的测定. 其中 DO 采用碘量法测定; BOD $_{5}$ 利用 BOD-System (OxDirect, Italy) 测定; COD 利用 CODReaktor ET108 测定;TN 和 TP 利用多离子微电脑测量仪测定;浊度利用 WGZ-1A 型浊度计测定.

\section{3 数据分析}

运用 Excel 处理数据及作图, 主成分分析 (PCA) 和典范对应分析 (CCA) 使用 Canoco 4.5 软件分析. 聚类 分析和非度量多维标度 (MDS) 主要采用大型多元分析软件 PRIMER V5.0, 样点聚类是基于物种相似性矩阵 的基础上使用其子模块 Cluster 分析. 多样性指数的计算使用其子模块 Diversity,包括 Margalef 丰富度指数 $(H) 、$ Shannon-Wiener 多样性指数 $\left(H^{\prime}\right) 、$ Pielou 均匀度指数 $(J)$ 及 Simpson 生态优势度指数 $(D)$, 计算公式分 别为: $H=(S-1) / \ln N, H^{\prime}=\sum_{i=1}^{S} P_{i} \ln P_{i}, J=H^{\prime} / \ln S, D=1-\sum_{i=1}^{S} P_{i}^{2}$. 式中, $S$ 为藻类植物属数; $N$ 为藻 类植物个体总数; $P_{i}$ 为第 $i$ 属的个体数 $\left(N_{i}\right)$ 占总个体数 $(N)$ 的比值.

优势度 $(y)$ 计算公式为: $y=f_{i} \cdot P_{i}$, 式中, $f_{i}$ 为 $i$ 种在采样点中的出现频率; $P_{i}$ 为 $i$ 种在总数量中的比例; $y>0.02$ 定为优势种 ${ }^{[21]}$.

\section{2 结果与讨论}

\section{1 安兴湿地秋季水体环境因子变化}

安兴湿地秋季水体水温波动幅度较大, 在 $7.3 \sim 14.5^{\circ} \mathrm{C}$ 之间变化, VIII点最高 $\left(14.5^{\circ} \mathrm{C}\right)$, II 点最低 $\left(7.3^{\circ} \mathrm{C}\right) . \mathrm{pH}$ 值变化范围为 $7.10 \sim 8.63, \mathrm{IX}$ 点 $\mathrm{pH}$ 值最高 $(8.63)$, II 点最低 $(7.10), \mathrm{pH}$ 平均值为 7.76 , 表明 秋季安兴湿地水体呈中性偏碱. 各采样点间 TP、TN 及 DO 的差异很大, TP $0.476 \sim 0.816 \mathrm{mg} / \mathrm{L}, \mathrm{TN} 1.19 \sim$ $3.67 \mathrm{mg} / \mathrm{L}$, DO $19.58 \sim 36.36 \mathrm{mg} / \mathrm{L}$, II 点 TP 及 DO 均最高, 分别为 $0.816 \mathrm{mg} / \mathrm{L} 、 36.36 \mathrm{mg} / \mathrm{L} . \mathrm{V}$ 点 TN 含量 最高 $(3.67 \mathrm{mg} / \mathrm{L})$, 而 DO 最低 $(19.58 \mathrm{mg} / \mathrm{L})($ 表 1$)$.

表 1 安兴湿地秋季采样点的环境因子

Tab. 1 The environmental factors of each sampling site in autumn of Anxing Wetland

\begin{tabular}{cccccccccc}
\hline 采样点 & $\begin{array}{c}\text { WT } \\
/{ }^{\circ} \mathrm{C}\end{array}$ & $\mathrm{pH}$ & $\begin{array}{c}\text { SpCond. } \\
(\mu \mathrm{S} / \mathrm{cm})\end{array}$ & $\begin{array}{c}\mathrm{DO} / \\
(\mathrm{mg} / \mathrm{L})\end{array}$ & $\begin{array}{c}\mathrm{COD} / \\
(\mathrm{mg} / \mathrm{L})\end{array}$ & $\begin{array}{c}\mathrm{BOD}_{5} / \\
(\mathrm{mg} / \mathrm{L})\end{array}$ & $\begin{array}{c}\mathrm{TP} / \\
(\mathrm{mg} / \mathrm{L})\end{array}$ & $\begin{array}{c}\mathrm{TN} / \\
(\mathrm{mg} / \mathrm{L})\end{array}$ & $\begin{array}{c}\mathrm{Turb} . / \\
\mathrm{NTU}\end{array}$ \\
\hline I & 10.5 & 7.66 & 256 & 30.34 & 76.2 & 10 & 0.560 & 3.39 & 89.5 \\
II & 7.3 & 7.10 & 242 & 36.36 & 62.6 & 9 & 0.816 & 3.13 & 88.9 \\
III & 8.7 & 7.40 & 258 & 34.69 & 70.5 & 8 & 0.476 & 3.02 & 82.2 \\
IV & 8.6 & 7.44 & 254 & 22.94 & 67.0 & 2 & 0.624 & 3.61 & 85.5 \\
V & 8.6 & 7.46 & 258 & 19.58 & 66.1 & 7 & 0.624 & 3.67 & 81.7 \\
VI & 13.4 & 7.93 & 277 & 20.33 & 63.0 & 3 & 0.704 & 1.61 & 107.2 \\
VII & 10.4 & 7.98 & 246 & 21.77 & 68.7 & 5 & 0.784 & 2.57 & 93.5 \\
VIII & 14.5 & 8.20 & 282 & 24.62 & 71.4 & 12 & 0.544 & 2.43 & 89.6 \\
IX & 11.8 & 8.63 & 275 & 29.65 & 77.5 & 6 & 0.504 & 1.19 & 105.9 \\
平均值 & 10.4 & 7.76 & 261 & 26.70 & 69.2 & 7 & 0.626 & 2.74 \\
\hline
\end{tabular}

安兴湿地秋季各采样点与环境变量之间的主成分 (PCA) 分析结果显示 (图 2), 第一、二轴特征值为 0.732 和 0.198 , 电导率、水温、 $\mathrm{pH}$ 、浊度及 COD 与第一轴呈正相关; 而 $\mathrm{TN}$ 与第一轴呈负相关; DO 与第二轴 呈负相关; $\mathrm{BOD}_{5}$ 与第二轴呈显著负相关 (图 2); 分析各采样点与环境因子相关性可以看出, I 点受 DO 影响 较大, I 点位于核心区域其水体流动缓慢; II 、III点与浊度呈负相关; IV 点分布较其它样点远, 受各指标的影 响很小, 说明 IV 点水质好于其它样点; $V$ 点受氮、磷营养盐的影响, 这与其靠近农田有关; VI点与 DO 轴呈负 相关; VII点受浊度影响较大, 由于VII 点位于人水口处, 水体流动较快, 水体易浑浊; VIII 点与 TP 轴相对, 与 TP 呈负相关; IX点受水温、电导率及 $\mathrm{pH}$ 三者影响较大.

\section{2 浮游植物种类组成、丰度及优势种}

2.2 .1 浮游植物种类组成 安兴湿地浮游植物优势门类主要为绿藻门和裸藻门,其次为硅藻门,调查期间共 


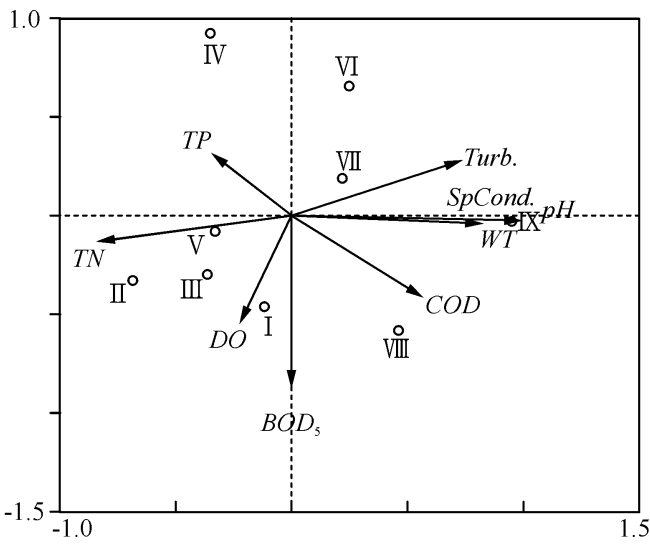

图 2 采样点与环境因子的主成分分析

Fig. 2 The principal component analysis of sampling sites and environmental factors

鉴定浮游植物 146 个分类单位, 隶属于 6 门 8 纲 12 目 25 科 45 属,其中绿藻门 19 属 48 种 10 变种, 裸藻门 5 属 41 种 4 变种,硅藻门 13 属 28 种 3 变种 1 变型, 蓝藻 门 5 属 7 种, 甲藻门 2 属 3 种, 隐藻门 1 属 1 种; 各门浮 游植物所占比例分别为 $39 \% 、 31 \% 、 22 \% 、 5 \%$ 、 $2 \%, 1 \%$.

各样点浮游植物种类组成差异显著 (图 3), IV 点 种类最为丰富, 共监测到浮游植物 64 种, 其中绿藻门 29 种、裸藻门 23 种、硅藻门 10 种、蓝藻门 1 种、隐藻门 1 种. VIII点中监测到的种类数最少, 仅观察到浮游植物 40 种, 其中绿藻门 16 种、裸藻门 8 种、硅藻门 14 种、蓝 藻门 2 种. 绿藻门的针形纤维藻 (Ankistrodesmus acicularis (A. Br. ) Korsch. )、四尾栅藻 (Scenedesmus quadricauda (Turp.) Bréb. ) 、二形栅藻 (Scenedesmus dimorphus ( Turp.) Kütz. )、螺旋弓形藻 ( Schroederia spiralis (Printz) Korsch.), 裸藻门的棘刺囊裸藻 ( Trachelomonas hispida (Perty) Steinem. Defl. )、旋转囊裸藻 (Trachelomonas volvocina Ehr. )、梨形扁裸藻 ( Phacus pyrum (Ehr.) Stein), 硅藻门的梅尼小环藻 (Cyclotella meneghiniana), 蓝藻门的拟短形颤藻 (Oscillatoria subbrevis Schm.) 等在各采样点均能监测到, 是安兴湿地中的常见藻类.

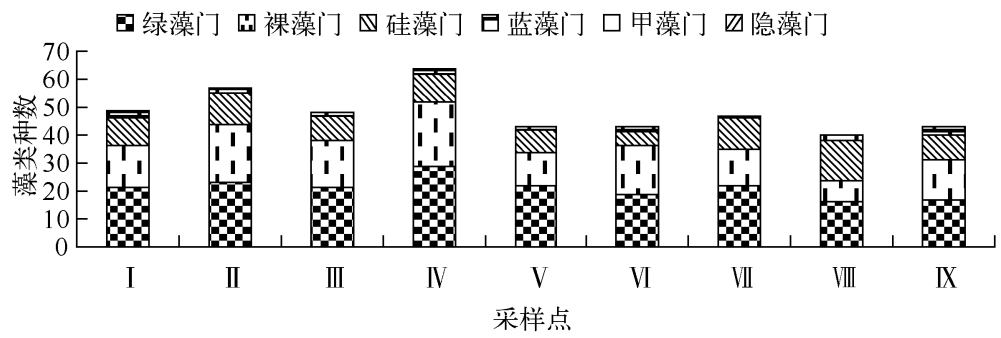

图 3 安兴湿地浮游植物群落组成

Fig. 3 The composition of phytoplankton community in Anxing Wetland

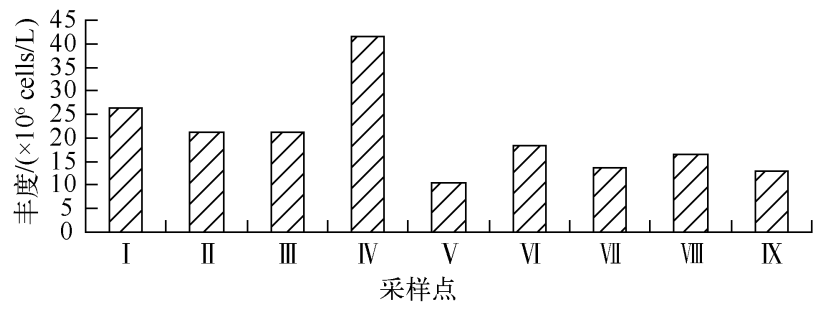

图 4 安兴湿地浮游植物丰度

Fig. 4 The density of phytoplankton in Anxing Wetland

2.2 .2 浮游植物丰度 安兴湿地秋季浮游 植物的总丰度为 $181.4 \times 10^{6} \mathrm{cell} / \mathrm{s} / \mathrm{L}$, 平均 丰度为 $30.2 \times 10^{6}$ cells $/ \mathrm{L}$. 其中裸藻门丰度 最大, 为 $80.9 \times 10^{6} \mathrm{cells} / \mathrm{L}$, 占总丰度的 $44.6 \%$; 绿藻门次之, 为 $50.2 \times 10^{6} \mathrm{cells} / \mathrm{L}$, 占总丰度的 $27.7 \%$; 硅藻门居第三位, 为 $39.6 \times 10^{6} \mathrm{cell} / \mathrm{s} / \mathrm{L}$, 占总丰度的 $21.8 \%$; 其 余依次为蓝藻门 $10.3 \times 10^{6} \mathrm{cells} / \mathrm{L}$, 占 $5.6 \%$; 甲藻门 $0.3 \times 10^{6}$ cells $/ \mathrm{L}$, 占 $0.2 \%$; 最少的为隐藻门, 仅为 $0.1 \times 10^{6}$ cells $/ \mathrm{L}$, 占 $0.06 \%$.

不同采样点之间浮游植物的丰度也存在一定差异 (图 4). 点 $\mathrm{IV}$ 浮游植物丰度最大, 为 $41.4 \times 10^{6} \mathrm{cells} / \mathrm{L}$, 点 $\mathrm{V}$ 浮游植物丰度最小, 为 $10.4 \times 10^{6} \mathrm{cells} / \mathrm{L}$, 其它样点浮游植物的丰度在 $13.1 \times 10^{6} \sim 26.3 \times 10^{6} \mathrm{cells} / \mathrm{L}$ 之 间,其中丰度较高的浮游植物种类有: 细粒囊裸藻 (Trachelomonas granulosa) 为 $34.4 \times 10^{6}$ cells $/ \mathrm{L}$; 梅尼小环 藻 $\left(\right.$ Cyclotella meneghiniana) 为 $15.7 \times 10^{6} \mathrm{cells} / \mathrm{L}$; 细粒囊裸藻齿领变种 (Trachelomonas granulosa var. crenu 
latocollis) 为 $11.2 \times 10^{6}$ cells $/ \mathrm{L}$; 拟短形颤藻 (Oscillatoria subbrevis) 为 $8.0 \times 10^{6}$ cells $/ \mathrm{L}$; 狭形纤维藻 (Ankistrodesmus angustus Bern.) 为 $7.1 \times 10^{6}$ cells $/ \mathrm{L}$ 等.

2.2 .3 浮游植物优势种 根据各样点中浮游植物出现的频率和相对丰度, 以优势度 $y>0.02$ 来界定优势 种 ${ }^{[21]}$. 对秋季安兴湿地内 9 个采样点的优势种进行比较可知: 细粒囊裸藻在所有样点中都为优势种, 可以作 为整个研究区域的指示种, 其中 $I V$ 点中优势度最大 $(y=2.40), \mathrm{V}$ 点中优势度最小 $(y=0.34)$; 另外, 梅尼小 环藻在 7 个样点中均为优势种类, VIII点的优势度最高 $(y=0.61), \mathrm{V}$ 点中优势度最低 $(y=0.04)$; 各样点的亚 优势种也存在差异, 其中, 点 I 的密集囊裸藻 (Trachelomonas crebea Kell. em. Defl. ) 为亚优势种; 点 II 、III 、IV 的亚优势种为细粒囊裸藻齿领变种; 点 $\mathrm{V}$ 和 IX 的矩圆囊裸藻 (Trachelomonas oblonga Lemm. ) 为亚优势种; 点 VI的旋转囊裸藻为亚优势种; VII 点的狭形纤维藻、美丽网球藻 (Dictyosphaerium pulchellum Wood) 为亚优势 种; 点VIII的细粒囊裸藻为亚优势种 (表 2).

\section{3 群落分布聚类分析和多维标度分析}

PRIMER 是基于以等级相似性为基础的非参数多元统计技术而开发的大型多元统计软件,已被广泛用 于海洋群落的结构、功能和生物多样性的研究,并逐渐向生态监测和环境评价的方向发展 ${ }^{[22]}$. 利用 PRIMER 对安兴湿地 9 个采样点群落分布进行聚类分析和 MDS 分析, 结果表明 9 个样点分成 5 组,组一包括样点 I、 II 、III VI 、VII, 表明浮游植物群落组成在这 5 个样点有一定相似性; 但样点 IV、VII 、IX、V 单独成组, 表明这 4 个样点在群落组成上存在一定差异性(图 5 ).
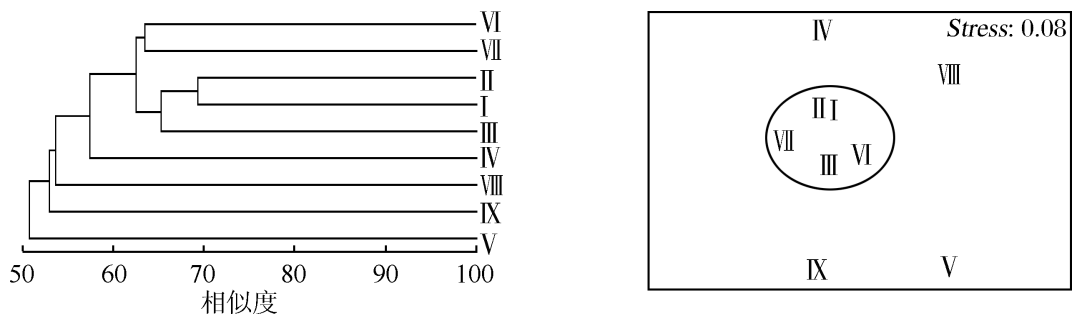

图 5 安兴湿地 9 个采样点聚类和 MDS 排序

Fig. 5 The cluster and MDS of nine sampling sites in Anxing Wetland

\section{4 优势种与环境因子典范对应分析}

根据优势度从各样点笁选出优势种共 10 个,运用典范对应分析 (CCA) 对优势种群与环境因子进行分 析 (图 6). 典范对应分析能同时结合多个环境因子分析,包含的信息量大, 结果直观明显, 能更好地反映群落 与环境的关系 ${ }^{[23]}$. 前两个排序轴的特征值分别为 0.135 和 0.050 . 环境因子轴与物种排序轴之间的相关系数 都为 1.000 ,物种一环境变异累积百分数分别为 $52.1 \%$ 和 $71.4 \%$. CCA 排序图反映出 10 个优势种对环境条 件的不同适应特点. 在 9 个环境因子中, $\mathrm{pH}$ 与水温对安兴湿地秋季优势种群的结构影响明显, 并且 $\mathrm{pH}$ 和水 温都与第一轴呈正相关, 相关系数分别为 $0.5766 、 0.5348$, 表明 $\mathrm{pH}$ 和水温是影响优势种分布的主要因子.

梅尼小环藻分布受水温和电导率影响较大, 这和它的生境特点相符 ${ }^{[18]}$; 美丽网球藻分布受 $\mathrm{pH}$ 和浊度 的影响较大; 囊裸藻属的优势种类与水温呈负相关关系, 都分布在与水温相对的一侧; 狭形纤维藻、拟短形 颤藻及颗粒直链藻极狭变种 (Melosira granulata var. angustissima O. Müller) 分布也受水温这个重要环境因子 的影响 ( 图 6).

\section{5 多样性指数分析}

目前在生态环境研究中多应用多样性指数来解释水体的自然状况,如奕青杉等 ${ }^{[24]}$ 利用多样性指数对长 江口水域浮游植物群落特征进行分析, 结果显示东南部海域浮游植物多样性程度较高, 物种均一性较好. 对 安兴湿地内各采样点浮游植物进行多样性指数分析可知, 不同采样点间浮游植物多样性指数除物种丰富度 指数波动幅度较大 $(7.629 \sim 10.450)$ 外, 其余各项指数波动幅度都较小. 各样点 Margalef 多样性指数 $H$ 值变 化范围为7.629 10.450 $(H>3)$ (表 3 ), 表明水体轻或无污染 ${ }^{[25]}$. Shannon-Wiener 多样性指数 $H^{\prime}$ 值变化范 围为 $1.243 \sim 2.385\left(H^{\prime}=1 \sim 3\right)$, 其中 $1 \sim 2$ 为 $\alpha$-中污染, $2 \sim 3$ 为 $\beta$-中污染 ${ }^{[26]}$, 说明安兴湿地水体呈中污染 
表 2 安兴湿地秋季浮游植物优势种及优势度

Tab. 2 Dominant species and the dominance of phytoplankton in autumn of Anxing Wetland

\begin{tabular}{|c|c|c|c|c|}
\hline 采样点 & 优势种 & 相对丰度/\% & 出现频率 $f$ & 优势度 $y$ \\
\hline \multirow[t]{4}{*}{ I } & 细粒囊裸藻 & 0.19 & 5.0 & 0.95 \\
\hline & 细粒囊裸藻齿领变种 & 0.11 & 2.8 & 0.31 \\
\hline & 拟短形㗜藻 & 0.07 & 1.8 & 0.13 \\
\hline & 密集囊裸藻 & 0.07 & 1.8 & 0.13 \\
\hline \multirow[t]{3}{*}{ II } & 细粒囊裸藻 & 0.20 & 4.3 & 0.86 \\
\hline & 梅尼小环藻 & 0.09 & 1.9 & 0.17 \\
\hline & 细粒囊裸藻齿领变种 & 0.06 & 1.3 & 0.08 \\
\hline \multirow[t]{3}{*}{ III } & 细粒囊裸藻 & 0.20 & 4.2 & 0.84 \\
\hline & 梅尼小环藻 & 0.08 & 1.8 & 0.14 \\
\hline & 细粒囊裸藻齿领变种 & 0.08 & 1.7 & 0.14 \\
\hline \multirow[t]{3}{*}{ IV } & 细粒囊裸藻 & 0.24 & 10.0 & 2.40 \\
\hline & 细粒囊裸藻齿领变种 & 0.08 & 3.4 & 0.27 \\
\hline & 密集囊裸藻 & 0.07 & 3.0 & 0.21 \\
\hline \multirow[t]{3}{*}{ V } & 细粒囊裸藻 & 0.18 & 1.9 & 0.34 \\
\hline & 梅尼小环藻 & 0.06 & 0.6 & 0.04 \\
\hline & 矩圆囊裸藻 & 0.05 & 0.5 & 0.03 \\
\hline \multirow[t]{3}{*}{$\mathrm{VI}$} & 细粒囊裸藻 & 0.22 & 4.1 & 0.90 \\
\hline & 梅尼小环藻 & 0.13 & 2.4 & 0.31 \\
\hline & 旋转囊裸藻 & 0.05 & 0.9 & 0.05 \\
\hline \multirow[t]{4}{*}{ VII } & 梅尼小环藻 & 0.13 & 1.8 & 0.23 \\
\hline & 细粒囊裸藻 & 0.12 & 1.6 & 0.20 \\
\hline & 狭形纤维藻 & 0.10 & 1.3 & 0.13 \\
\hline & 美丽网球藻 & 0.04 & 0.8 & 0.03 \\
\hline \multirow[t]{3}{*}{ VIII } & 梅尼小环藻 & 0.19 & 3.2 & 0.61 \\
\hline & 颗粒直链藻极狭变种 & 0.14 & 2.3 & 0.32 \\
\hline & 细粒囊裸藻 & 0.07 & 1.1 & 0.08 \\
\hline \multirow[t]{4}{*}{ IX } & 细粒囊裸藻 & 0.17 & 2.2 & 0.37 \\
\hline & 梅尼小环藻 & 0.08 & 1.1 & 0.09 \\
\hline & 旋转囊裸藻 & 0.07 & 0.9 & 0.06 \\
\hline & 矩圆囊裸藻 & 0.06 & 0.8 & 0.05 \\
\hline
\end{tabular}

表 3 安兴湿地秋季浮游植物多样性指数

Tab. 3 The diversity indexes of phytoplankton in autumn of Anxing Wetland

\begin{tabular}{crccc}
\hline 采样点 & \multicolumn{1}{c}{$H$} & $J$ & $H^{\prime}$ & $D$ \\
\hline I & 8.614 & 0.8178 & 2.183 & 0.9296 \\
II & 10.450 & 0.8373 & 2.385 & 0.9342 \\
III & 8.588 & 0.8174 & 2.147 & 0.9266 \\
IV & 10.290 & 0.7635 & 2.163 & 0.9134 \\
V & 8.846 & 0.8870 & 1.315 & 0.9407 \\
VI & 8.045 & 0.8244 & 2.101 & 0.9169 \\
VII & 9.174 & 0.8560 & 2.277 & 0.9407 \\
VIII & 7.629 & 0.8358 & 2.083 & 0.9231 \\
IX & 8.906 & 0.8569 & 1.243 & 0.9363 \\
\hline
\end{tabular}

状态. Pielou 均匀度指数 $J$ 值变化范 围为 $0.7635 \sim 0.8870(J<1), J$ 值接 近于 1 , 体现出属间个体数分布较均 匀的特征 ${ }^{[27]}$. Simpson 生态优势度指 数 $D$ 值范围为 $0.9134 \sim 0.9407$ $(D<1)^{[28]}$, 表明安兴湿地内浮游植 物群落个体分散, 群落内物种丰度较 均匀.

\section{3 讨论}

\section{1 浮游植物群落组成}

浮游植物是水体中最为基础的参 与者,也是水生态系统中不可缺少的 组成成分, 浮游植物的变动必然会导 致生态现象的变化, 并且浮游植物的 种群结构与其生活水域的水质状况密 切相关, 在不同营养状态的水体中, 分 布着不同种群结构的浮游植物 ${ }^{[7]}$, Chen 等 ${ }^{[29]}$ 曾指出台北三个人工湿地 中生物组成与非生物组成都是完全不 同的.

2010 年秋季分别对安兴湿地的 核心区、灌溉区、农田区、近村庄、道路 旁、人水口和出水口进行采样及调查, 共发现浮游植物 146 个分类单位. 从 浮游植物组成上看, 以绿藻门为主, 其 次为裸藻门、硅藻门, 蓝藻门、甲藻门、 隐藻门等所占比例较低, 由于各采样 点所处的环境条件不同, 浮游植物水 平分布存在差异 (图 6), 不同样点间浮 游植物丰度分布差异性也很大( 图 4).

从各采样点浮游植物种类组成 (图 3) 和丰度 (图 4) 上看, 核心区点 I 和灌溉区点 III 浮游植物种类组成相 似, 两样点水温相对较其他样点低, 水 体呈弱碱性, 在群落组成上, 样点 I 有 甲藻出现, 并且水体中出现了嗜碱性 种类, 如: 隐头舟形藻 (Navicula cryptocephala Kütz.) 、弯棒杆藻 (Rhopabdia gibba (Ehr.) O. Müller), 还有仅在点 III 中出现的意大利直链藻 (Melosira italica (Ehr. ) Kütz. ); 核心区点 II 浮 游植物种类组成较点 $\mathrm{IV}$ 简单, 并且点 II 水温最低, 对水温适应性强的微小 色球藻 (Chroococcus minutus (Kütz.) Näg. ) 出现; 位于灌溉区的点 IV 种类 


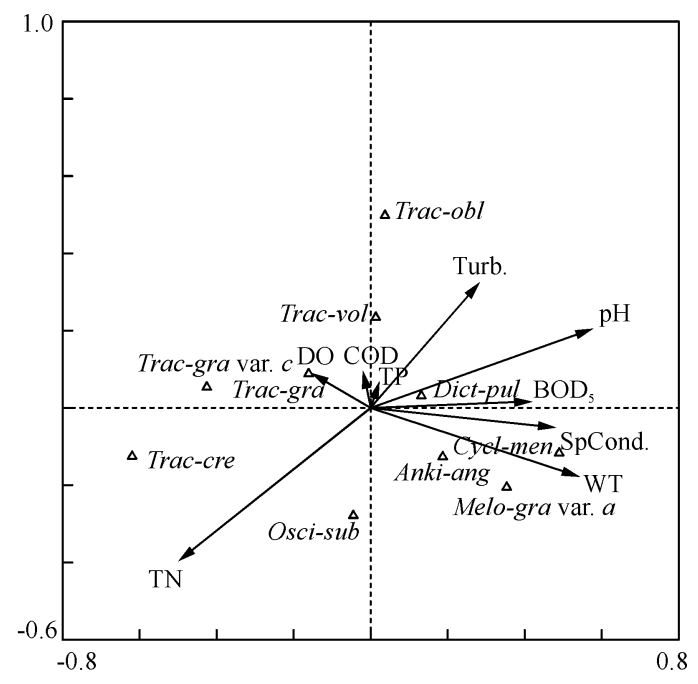

图 6 优势种群典范对应分析 (Trac-gra = Trachelomonas granulosa, Trac-gra var. $c=$ Trachelomonas granulos $a$ var. crenulatocollis, Trac-cre $=$

Trachelomonas crebea, Trac-vol = Trachelomonas volvocina, Trac-obl $=$

Trachelomonas oblonga, Osci-sub = Oscillatoria subbrevis, Anki-ang = Ankistrodesmus angustus,Melo-gra var. a=Melosira granulata var. angustissima, Cycl-men = Cyclotella meneghiniana, Dict-pul $=$ Dictyosphaerium pulchellum $)$

Fig. 6 The canonical correspondence analysis to dominant species

分布最多, 而且丰度也最高, 其水温和 $\mathrm{pH}$ 值都较平均值低, 从点 $\mathrm{IV}$ 整体来看, 主要以绿藻占优势, 并且在所 有样点中IV 点绿藻丰度最高 (图 3), 多为静止水体常见的普生性种类, 如: 螺旋弓形藻 (Schroederia spiralis) 、 二角盘星藻大孔变种 (Pediastrum duplex var. clathratum A. Brun.) 等. 主成分分析 (图 2) 表明样点 IV 受理化 指标影响很小, 水质相对较好; 位于农田区的点 $\mathrm{V}$ 种类分布相对较少, 浮游植物丰度低, 水温和 $\mathrm{pH}$ 适中, 但 $\mathrm{TN}$ 含量相对较高, 使得该样点群落结构相对简单, 还检测出了池塘、稻田中常见的裸藻门植物如梨形扁裸 藻 (Phacus pyrum)、尖尾裸藻 (Euglena oxyuris Schmarda) 等, 裸藻门植物喜欢生活在有机质丰富的水体中, 表 明点 V 有机质含量丰富; 靠近村庄的点 VI 、人水口点 VII 以及出水口点 IX 浮游植物种类组成相近, 由于点 VII 和 点 $\mathrm{X}$ 位于出、人水口, 水体流速相对较快, 所以在浮游植物丰度上点 VI略高于其它两个样点, 蓝藻门的卷曲 鱼腥藻 (Anabaena circinalis Rab.) 和阿氏项圈藻 (Anabaenopsis arnoldii Aptek.) 仅在点 $\mathrm{X}$ 有分布; 靠近湿地路 旁的点VIII种类分布最少, 水温最高, 电导率也最大, 水体呈碱性 (表 1), 由于其靠近道路受人为活动的影响导 致种类分布明显减少. 同时各样点聚类和 MDS 排序分析 (图 6) 也表明, 浮游植物群落结构与水体生境相适 应, 聚类分析将生境特殊的样点 IV、V、VIII、IX 单独笁选出来, 各样点都具有明显生境特征, 其中样点 IV 浮游 植物丰度最高, 而其它 3 个样点的浮游植物丰度都很低. 结合 MDS 排序也可以看出, 排序结果与聚类结果相 符, 并且 MDS 排序的胁强系数为 0.08 ( Stress $<0.1$ 说明是一个很好的排序 ${ }^{\left[{ }^{[0]}\right.}$ ), 具有一定的代表性, 进一步 验证了聚类分析的结果, 可以看出安兴湿地内各样点浮游植物群落结构组成差异性大,相似性低.

\section{2 浮游植物群落结构与环境的相关性}

影响水体中浮游植物群落结构的环境因子很多, 主要有营养盐、温度和光照 ${ }^{[31]}$. 安兴湿地浮游植物群落 结构受季节因素影响较大, 秋季水温相对低, 光照不充分. 相对其它浮游植物群落, 蓝藻生长需要更高的温 度, 最适温度为 $25 \sim 35^{\circ} \mathrm{C}^{[32-34]}, 15^{\circ} \mathrm{C}$ 以下其生长会受到限制 ${ }^{[35]}$, 难以成为优势种群. 而安兴湿地秋季浮游植 物群落结构以绿藻占优势, 由于降水的影响, 湿地周边农田用药的残留会随径流流人湿地中, 如氮、磷营养 盐等, 在营养盐浓度偏高的水体中绿藻易成为优势种 ${ }^{[36]}$.

此外, 湿地结构和水文形势对群落结构也有一定影响, Borics 等 ${ }^{[37]}$ 指出水文形势和生境多样性是影响 匈牙利 12 个沼泽湖中浮游植物种类及其丰度的主要因素. 从各样点浮游植物种类及丰度差异可以看出, 核 
心区 $(I 、 I I)$ 和灌溉区 $($ III ) 水体流动都缓慢, 核心区不受外界的干扰, 灌溉区秋季农田用水量明显减少, 导 致两个区域水体滞留时间长, 使得浮游植物种类和丰度都不多, 群落结构相对简单, 细粒囊裸藻及其变种为 优势种群; 样点 IV 虽然也位于灌溉区但其水域面积宽广, 水体较为开阔, 较点 III 水体流通性好, 结合各项分 析表明点 $\mathrm{V}$ 水质好于其它样点, 所以种类多、丰度高; 样点 $\mathrm{V}$ 位于农田区, 地势较其他样点低又靠近农田, 受 农业生产影响大, 主成分分析 (图 2) 也表明,农业中施用的化学药物会随着地面的径流流回湿地, 从而影响 种类和丰度的分布, 样点 $\mathrm{V}$ 浮游植物丰度最小、种类少, 其中包括一些耐污种类, 如绿色裸藻 (Euglena viridis Ehr.) 、中型裸藻 (Euglena intermedia (Klebs) Schmitz) 等; 样点 VI靠近村庄, 但不受人为活动和生活污水影 响, 种类组成及丰度变化不明显; 人水口样点 VII 水流速度相对较快, 极易引起水体浑浊, 水体透明度也会随 之降低, 从而影响了浮游植物的群落结构; 样点 VIII靠近道路, 受过往车辆及人为活动的干扰, 种类分布最少, 仅监测到 40 个分类单位; 出水口点 IX 位于湿地边缘, 由于受光照相对充足导致其温度偏高, 蓝藻门植物明 显增加 (图 4).

通过对优势种群的 CCA 分析表明,优势种的分布受温度和 $\mathrm{pH}$ 这两个环境因子影响最大. 囊裸藻属的 种类, 如细粒囊裸藻、细粒囊裸藻齿领变种、密集囊裸藻等与温度呈显著负相关, 这说明囊裸藻属的种群在 温度较低的条件下生长很好, 从而成为优势种, Philipose ${ }^{[38]}$ 在印度裸藻的分类中提到, 多数囊裸藻经常出现 在温度低并且有机质丰富的水体中. 梅尼小环藻在 7 个样点中都有分布, 并且属于嗜盐、嗜碱性种类, 与安 兴湿地高电导率、偏碱性的水体生境相符. 颗粒直链藻极狭变种在样点 VIII 中优势度最大, 而且样点 VIII温度最 高, $\mathrm{pH}$ 呈碱性, 适宜喜碱性种类——颗粒直链藻极狭变种的生长. 美丽网球藻分布受 $\mathrm{pH}$ 和浊度的影响, Irfanullah $^{[39]}$ 等指出美丽网球藻在 Delamere 湖成为优势种, 是由于其 $\mathrm{pH}$ 耐受范围广, 同时可以耐受高浊度, 美 丽网球藻适宜的 $\mathrm{pH}$ 范围为 $3.3 \sim 8.5$.

综上分析, 秋季安兴湿地的类型属于绿藻一裸藻型, 大部分藻类属于普生性种类, 间有污染指示种出 现. 安兴湿地内浮游植物丰度高、种类多,物种组成丰富. 优势种群分析显示优势种的分布具有种类少、个体 数量大的特点. Pielou 指数及 Simpson 指数结果表明, 安兴湿地内浮游植物群落分布较为均匀. 聚类分析结 果与浮游植物评价结果相一致, 进一步证实了水体环境可以影响浮游植物种群或群落的结构特征. 此外, 在 各样点中还监测到大量 $\beta$-中污染指示物种, 如梅尼小环藻、尖针杆藻 (Synedra acus Kütz. )、绿色裸藻、实球 藻 (Pandorina morum (Müll.) Bory.)、旋转囊裸藻、新星形冠盘藻 (Stephanodiscus neoastraea Häkansson et Hickel) 及衣藻 (Chlamydomonas sp. ) 等, 表明水质变化与浮游植物个体和种群的变化密切相关, 也客观地反映 出浮游植物是较好的监测指示生物. 结合 Margalef 指数及 Shannon-Wiener 指数分析结果 (表 3), 安兴湿地水体 可能处于中度污染水平, 水质下降可能源于营养盐流人. 这些营养盐主要来自湿地内围网养殖以及灌溉用水 回流, 其在湿地内逐渐积累, 使得安兴湿地自净能力下降. 虽然安兴湿地已列为保护区, 但从水体状况可以看 出保护力度还不足,因此应采取相应的措施来改善和保护该湿地的生态资源, 以防止水体进一步恶化.

致谢: 本文 CCA 分析得到中国科学院南京地理与湖泊研究所羊向东研究员的指导; 刘妍老师、惠洪宽、宋楠 同学在野外采集工作中提供大量帮助; 耐美卡 (Nnaemeka Okpala) 先生对英文摘要提出修改意见; 在此一并 表示衰心的感谢.

\section{4 参考文献}

[ 1 ] Cardinale BJ, Palmer MA, Collins SL. Species diversity enhances ecosystem functioning through interspecific facilitation. Nature,2002, 415 : 426-429.

[2] Suikkanen S, Laamanen M, Huttunen M. Long-term changes in summer phytoplankton communities of the open northern Baltic Sea. Estuarine, Coastal and Shelf Science, 2007, 71: 580-592.

[ 3 ] Diaz MM, Pedrozo FL, Temporetti PF. Phytoplankton of two Araucanian lakes of differing trophic status (Argentina). Hydrobiologia, 1998, 369/370 : 45-57.

[ 4 ] Lepistö L, Holopainen AL, Vuoristo H et al. Type-specific and indicator taxa of phytoplankton as a quality criterion for assessing the ecological status of Finish boreal lakes. Limnologica, 2004, 34: 236-248.

[5] 李秋华, 韩博平. 南亚热带调水水库春季浮游植物群落的结构与动态. 热带亚热带植物学报, 2007, 15 ( 4 ): 294-300.

[6] 覃雪波, 黄璞祎, 于洪贤等. 安邦河湿地浮游植物数量与环境因子相关性研究. 海洋湖沼通报, 2008, (3): $43-51$. 
[ 7 ] 孟顺龙, 陈家长, 范立民等. 2007 年太湖五里湖浮游植物生态学特征. 湖泊科学, 2009, 21 (6) : 845-854.

[ 8 ] 陈家长, 孟顺龙, 尤 洋等. 太湖五里湖浮游植物群落结构特征分析. 生态环境学报, 2009, 18(4): 1358-1367.

[ 9 ] 梁伟华, 谢洪鹏. 安兴湿地自然保护区的评价与效益分析. 东北水利水电, 2007, 25(8): 56-57.

［10］金相灿，屠清瑛，章宗涉等.湖泊富营养化调查规范:第 2 版. 北京: 中国环境科学出版社，1990.

[11］沈暳芬，章宗涉，龚循矩等. 微型生物监测新技术. 北京：中国建筑工业出版社, 1990.

[12］ 胡鸿钧, 魏印心. 中国淡水藻类——系统、分类及生态. 北京: 科学出版社, 2006.

[13] 胡鸿钧, 李尧英, 魏印心等. 中国淡水藻类. 上海: 上海科学技术出版社, 1979.

[14] 黎尚豪, 毕列爵. 中国淡水藻志第五卷绿藻门. 北京: 科学出版社, 1998.

[15］范亚文. 黑龙江省管壳缝目植物研究. 哈尔滨: 东北林业大学出版社, 2004.

[16] Krammer K, Lange-Bertalot H. Bacillariophyceae 1. Teil: Naviculaceae. Berlin: Spektrum Akademischer Verlag Heidelberg, 1997.

[17] Krammer K, Lange-Bertalot H. Bacillariophyceae 2. Teil: Bacillariaceae, Epithemiaceae, Surirellaceae. Berlin: Spektrum Akademischer Verlag Heidelberg, 1997.

[18 ] Krammer K, Lange-Bertalot H. Bacillariophyceae 3. Teil: Centrales, Fragilariaceae, Eunotiaceae. Berlin: Spektrum Akademischer Verlag Heidelberg, 2004.

[19] Hustedt F. Die Susswasser Flora Mitteleuropas, Bacillariophyta (Diatomeae). Jena: Verlag von Gustav Fischer, 1930.

[20］王全喜, 曹建国, 刘 妍等. 上海九段沙湿地自然保护区及其附近水域藻类图集. 北京: 科学出版社, 2008.

[21] Lampitt RS, Wishner KF, Turley CM et al. Marine snow studies in the northeast Atlantic: distribution, composition and roles as a food source for migrating plankton. Marine Biology, 1993, 116(4) :689-702.

[22] 周 红, 张志南. 大型多元统计软件 PRIMER 的方法原理及其在底栖群落生态学中的应用. 青岛海洋大学学报, 2003, 33(1) :58-64.

[23] 张金屯. 植被与环境关系的分析 II : CCA 和 DCCA 限定排序. 山西大学学报: 自然科学版, 1992, 15(3) : 292-298.

[24] 奕青杉, 孙 军. 2005 年夏季长江口水域浮游植物群集特征及其与环境因子的关系. 生态学报, 2010, 30(18): $4967-4975$.

[25] Brower JE, Zar JH, von Ende CN. Field and laboratory methods for general ecology. Boston: Brown Publishers, 1977 : 136-145.

[26] 吴 波. 上海苏州河、黄浦江浮游植物群落结构及其对环境指示作用的研究 [ 学位论文]. 上海: 上海师范大 学, 2006 .

[27] 蔡燕红. 杭州湾浮游植物生物多样性研究 [学位论文]. 青岛: 中国海洋大学, 2006.

[28] 李冠国. 多样性指数的应用. 海洋科学, 1981, 5(1):4-8.

[29] Chen PY, Lee PF, Ko CJ et al. Associations between water quality parameters and planktonic communities in three constructed wetlands, Taipei. Wetlands, 2011, 31(6) : 1241-1248.

[30] Khalaf MA, Kochzius M. Changes on tropic community structure of shore fishes at an industrial site in the gulf of Aqaba, Red Sea. Marine Ecology Progress Series, 2002, 239: 287-299.

[31] 林少君, 顾继光, 魏 鹏等. 广东省公平水库与星湖生态特征的对比分析. 生态学杂志, 2005, 24(7) : 773-779.

[32] Konopka A, Brock TD. Effect of temperature on blue-green algae(Cyanobacteria) in Lake Mendota. Applied and Environmental Microbiology, 1978, 36(4) : 572-576.

[33] 林毅雄, 韩 梅. 滇池富营养化的铜绿微囊藻 (Microcystis aeruginosa Kütz.) 生长因素的研究. 环境科学进展, $1998,6(3): 82-87$.

[34] Nalewajko C, Murphy TP. Effects of temperature and availability of nitrogen and phosphorus on the abundance of Anabae$n a$ and Microcystis in Lake Biwa, Japan: an experimental approach. Limnology, 2001, 2(1) : 45-48.

[35] Robarts RD, Zohary T. Temperature effects on photosynthetic capacity, respiration, and growth rates of bloom-forming cyanobacteria. Marine and Freshwater Research, 1987, 21: 391-399.

[36] 朱 伟, 万 蕾, 赵联芳. 不同温度和营养盐质量浓度条件下藻类的种间竞争规律. 生态环境, 2008, 17(1): 6-11.

[37] Borics G, Tóthmćrćsz B, Grigorszky I et al. Algal assemblage types of bog-lakes in Hungary and their relation to water chemistry, hydrological conditions and habitat diversity. Hydrobiologia, 2003, 502 : 145-155.

[38 ] Philipose MT. Contributions to our knowledge of Indian algae-3. Euglenineae Part 3. The genera Trachelomonas Ehrenberg and Strombomonas Deflandre. Proceedings of the Indian Academy of Science, 1988, 98(5) : 317-394.

[39] Irfanullah HM, Moss B. Ecology of Dictyosphaerium pulchellum Wood (Chlorophyta, Chlorococcales) in a shallow, acid, forest lake. Aquatic Ecology, 2006, 40: 1-12. 